\title{
A study on the effect of leverage on firms' management opportunism behavior
}

\author{
Mehran Matinfard ${ }^{\mathrm{a}}$ and Reza Ojaghi ${ }^{\mathrm{b}^{*}}$
}

${ }^{a}$ Department of Management, Islamic Azad University, North Tehran Branch, Tehran, Iran ${ }^{b}$ Department of Management, Islamic Azad University, Najaf Abad Branch, Najaf Abad, Iran

\section{H R O N I C L E}

\section{Article history:}

Received May 12, 2013

Received in revised format

12 August 2013

Accepted 14 August 2013

Available online

September 52013

Keywords:

Tehran Stock Exchange

Earnings management

Discretionary accruals

\section{A B S T R A C T}

\begin{abstract}
This paper presents an empirical investigation to study the relationship between the opportunism behavior and leverage. In this study, opportunism behavior is calculated based on discretionary accruals using the method proposed by Jones [Jones, J. J. (1991). Earnings management during import relief investigations. Journal of accounting research, 29(2), 193228.]. In addition, the proposed study uses return on assets, return on equities, financial burden and financing for investigation. Using statistical data from Tehran Stock Exchange over the period 2006-2011, the study applies linear regression model and the results have indicated a positive and meaningful relationship between leverage and discretionary accruals, which is also called earnings management.
\end{abstract}

(C) 2013 Growing Science Ltd. All rights reserved.

\section{Introduction}

Earnings management plays essential role on having sustainable growth in most business firms (Barton \& Simko, 2002; Klapper, \& Love, 2004). Jensen and Meckling (1976) studied the relationship between the owners and managers where each part try to maximize their own benefits and since there was not a unique flow of information between these two groups it was observed a conflict of interest among them. They reported that corporate governance could help reduce any existing conflict and provide a fair flow of information between two parties. According to Maranjory et al. (2013), earnings management via discretionary accruals is a manager's instrument for changing stock holders' expectations and investigated the role of discretionary accruals in the earnings management of Iranian firms listed on Tehran Stock Exchange. The result of their study indicated that there was a relationship between earnings smoothness and discretionary accruals variables. It means that discretionary accruals (DA) could lead to the converse relationship among discretionary accruals variation and current and future cash flow. They also reported that the firms with high variation in Iran could utilize more discretionary accruals compared with the firms with lower

*Corresponding author. Tel: +989126037270

E-mail address: rezaojaghi89@yahoo.com (R. Ojaghi) 
variation did. Dechow et al. (1995) reported that nondiscretionary accruals were fixed and they were not supposed to be implemented for smoothing earnings and earnings managements occur due to discretionary accruals. Gosh and Olsen (2009) performed a research reporting that the managers make use of discretionary accruals for reducing earnings frequency.

Teoh et al. (1998) reported that IPO smoothing firms manage their earnings via discretionary accruals. In fact, there was a significant converse relationship among the discretionary accruals, future net, and cash flow variations. Based on their findings, the discretionary accruals were in a high rank in the year when the firm offered its stock for the first time; and the accruals maintained negative relationship with future net income and operational cash flows.

Panahian et al. (2012) presented an empirical investigation to find the relationship between discretionary accruals quality as well as innate accruals quality and portion of non-executive board of directors, concentration of ownership ratio and board size in Tehran Stock Exchange. The survey selected 118 qualified stocks from this exchange and by applying a random technique selected 42 firms. The study used two linear regression techniques to estimate the first part of the information and then using structural equation modeling examined six hypotheses. Based on the results of this survey they concluded that an increase on non-executive members positively impacted on discretionary accruals quality and negatively influenced innate accruals quality. In addition, concentration of ownership ratio positively affected on discretionary accruals quality and negatively influenced on innate accruals quality. Finally, size of board of directors negatively impacted discretionary accruals quality and positively impacted on innate accruals quality.

\section{The proposed study}

In this paper, we present an empirical investigation to study the relationship between the opportunism behavior and leverage. In this study, opportunism behavior is calculated based on discretionary accruals using the method proposed by Jones (1991). In addition, the proposed study uses return on assets, return on equities, financial burden and financing for investigation. The sample data are gathered from the information of firms whose shares are listed on Tehran Stock Exchange. In this study, we have collected the information of the firms whose shares were actively traded on stock exchange. In addition, we only considered the information of the firms whose financial information were reported on stock exchange on regular basis and the share was not interrupted more than six months.

Opportunism behavior is considered as dependent variable $\left(Y_{i}\right)$ and in this study, we measure this variable based on discretionary accruals (DA) using Jones's formula (Joens, 1991) and leverage is the independent variable, which is measure using debt ratio, i.e. total liabilities/total assets. In addition, there are four control variables in our study. The first control variable, return on assets (ROA), is measured as net earnings/total assets and the second control variable, return on equities (ROE), is also calculated as net earnings/total equities. Financing $(\mathrm{F})$ is the third control variable, which is calculated as working capital/total assets and finally, financial burden (FB) is the last control variable, which is calculated as financial expenses/total liabilities. The proposed study uses the following linear regression model to test the hypotheses of this survey.

$$
Y_{i}=\beta_{0}+\beta_{1} D A_{i}+\beta_{2} R O A_{i}+\beta_{3} R O E_{i}+\beta_{4} F+\beta_{5} F B+\varepsilon_{i},
$$

where $\varepsilon_{i}$ is the residuals. Before we do the regression model we need to make sure that the data are normally distributed. This is accomplished using One-Sample Kolmogorov-Smirnov Test summarized in Table 1 as follows, 
Table 1

The summary of One-Sample Kolmogorov-Smirnov Test

\begin{tabular}{|c|c|c|c|c|c|c|c|}
\hline & & ROA & ROE & Leverage & FB & $\mathrm{F}$ & DA \\
\hline $\mathrm{N}$ & & 400 & 400 & 400 & 400 & 400 & 400 \\
\hline \multirow{2}{*}{$\begin{array}{l}\text { Normal } \\
\text { Parameters } \\
\text { a,b }\end{array}$} & Mean & 10.0936 & 105.2278 & 0.6837 & 0.0582 & 0.0298 & 0.7138 \\
\hline & $\begin{array}{c}\text { Std. } \\
\text { Deviation }\end{array}$ & 16.33411 & 1443.5401 & 0.26456 & 0.03945 & 0.30207 & 0.69945 \\
\hline \multirow{3}{*}{$\begin{array}{l}\text { Most } \\
\text { Extreme } \\
\text { Differences }\end{array}$} & Absolute & 0.16 & 0.469 & 0.123 & 0.074 & 0.121 & 0.154 \\
\hline & Positive & 0.127 & 0.469 & 0.123 & 0.074 & 0.09 & 0.149 \\
\hline & Negative & -0.16 & -0.429 & -0.086 & -0.07 & -0.121 & -0.154 \\
\hline \multicolumn{2}{|c|}{ Kolmogorov-Smirnov Z } & 3.208 & 9.39 & 2.452 & 1.489 & 2.42 & 3.081 \\
\hline \multicolumn{2}{|c|}{ Asymp. Sig. (2-tailed) } & 0.000 & 0.000 & 0.000 & 0.024 & 0.000 & 0.000 \\
\hline
\end{tabular}

As we can observe from the results of One-Sample Kolmogorov-Smirnov Test, none of the parameters is normally distributed and we need to choose non-parametric tests to verify the hypotheses of this survey. However, when we look at the graph of the residuals, we realize that the distributions of the sample data are close to normal (Fig. 1).

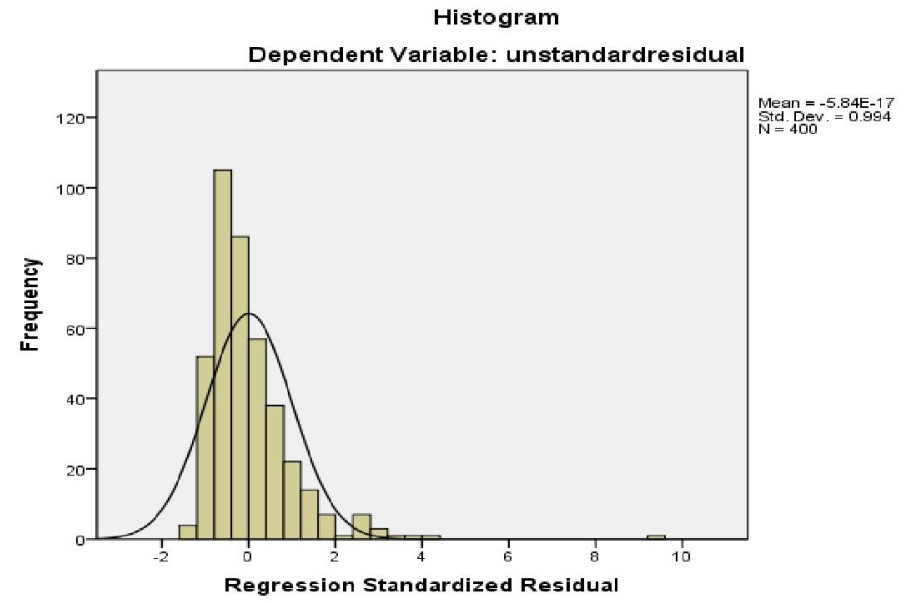

Fig. 1. The summary of residuals

\section{The results}

In this section, we present details of our investigation on testing the hypothesis of this survey using the regression model presented in Eq. (1).

\section{Table 2}

The summary of regression analysis

\begin{tabular}{|c|c|c|c|c|c|}
\hline \multirow[b]{2}{*}{ Model } & \multicolumn{2}{|c|}{ Non-standard coefficients } & \multirow{2}{*}{$\frac{\text { Standard coefficients }}{\beta}$} & \multirow[b]{2}{*}{ t-student } & \multirow[b]{2}{*}{ P-value } \\
\hline & $\beta$ & Standard deviation & & & \\
\hline$\beta_{0}$ (Intercept) & .030 & .170 & & .179 & .858 \\
\hline$\beta_{1}$ (Leverage) & .914 & .223 & .346 & 4.093 & .000 \\
\hline$\beta_{2}(\mathrm{REA})$ & .003 & .003 & .062 & 1.002 & .317 \\
\hline$\beta_{3}(\mathrm{ROE})$ & .000 & .000 & -.013 & -.257 & .797 \\
\hline$\beta_{4}(\mathrm{FB})$ & .269 & .956 & .015 & .282 & .778 \\
\hline$\beta_{5}(\mathrm{~F})$ & .561 & .172 & .242 & 3.266 & .001 \\
\hline
\end{tabular}


The results of Table 2 demonstrate the results of the regression model. In our survey, Durbin-Watson ratio is within an acceptable value, which means there is no correlation between residuals of the data. In addition, $t$-student values associated with leverage and financing are meaningful when the level of significance is one percent.

As we can observe from the results of Table $2, \beta_{1}$ is the coefficient of leverage, which shows the relationship between leverage and discretionary accruals. In other words, when there is an increase on leverage, there is more opportunism behavior associated with management of firms in our proposed study.

\section{Conclusion}

In this paper, we have presented an empirical investigation to study the relationship between leverage and discretionary accruals on some selected firms listed on Tehran Stock Exchange over the period 2006-2011. The proposed study has implemented linear regression technique and using four control variables, we have examined the effects of leverage on discretionary accruals. The result of our survey has indicated that there was a positive and meaningful relationship between these two variables.

\section{Acknowledgment}

The authors would like to thank the anonymous referees for constructive comments on earlier version of this paper.

\section{References}

Barton, J., \& Simko, P. J. (2002). The balance sheet as an earnings management constraint. The Accounting Review, 77(s-1), 1-27.

Dechow, P. M., Sloan, R. G., \& Sweeney, A. P. (1996). Causes and consequences of earnings manipulation: An analysis of firms subject to enforcement actions by the sec. Contemporary accounting research, 13(1), 1-36.

Ghosh, D., \& Olsen, L. (2009). Environmental uncertainty and managers' use of discretionary accruals. Accounting, Organizations and Society, 34(2), 188-205.

Jensen, M.C., \& Meckling, W.H. (1976). Theory of the firm: managerial behavior, agency costs and ownership structure. Journal of Financial Economics, 3(40), 305-360.

Jones, J. J. (1991). Earnings management during import relief investigations. Journal of Accounting Research, 29(2), 193-228.

Klapper, L.F., \& Love, I. (2004). Corporate governance, investor protection, and performance in emerging markets. Journal of Corporate Finance, 10(5), 703-728.

Maranjory, M., Alikhani, R., Zabihzadeh, A., \& Sepehri, P. (2013). The role of discretionary accruals in earnings management: Evidence from Tehran Stock Exchange. Management Science Letters, 3(9), 2399-2404.

Panahian, H., Ghodrati, H., \& Nazari, M. (2012). Innate and discretionary accruals quality and corporate governance: A case study of Tehran Stock Exchange. Management Science Letters, 2(8), 3023-3030.

Teoh, S. H., Welch, I., \& Wong, T. J. (1998). Earnings management and the long-run market performance of initial public offerings. The Journal of Finance,53(6), 1935-1974. 